\title{
Deriving Ecological Protective Concentration of Cadmium for Korean Soil Environment
}

\author{
Woo-Mi Lee, Sun-Hwa Nam, Youn-Joo $\mathrm{An}^{\dagger}$ \\ Department of Environmental Science, Konkuk University, Seoul 143-701, Korea
}

\begin{abstract}
For effective and efficient environmental management, developed countries, such as the Netherlands, UK, Australia, Canada, and United States apply ecological risk assessment, and they have an autonomous risk assessment methodology to protect native receptors. In this study, soil ecological protective concentration (EPC) of cadmium in Korea was derived using Korean ecological risk assessment methodology. The soil EPC of cadmium was calculated using probabilistic ecological risk assessment based on species sensitivity distribution. The soil EPC was calculated according to land use for residential/agricultural and industrial/commercial purposes. The chronic soil EPCs for residential/agricultural and industrial/commercial lands were derived to be 1.58 and $9.60 \mathrm{mg} / \mathrm{kg}$, respectively. These values were similar to soil EPC of European Commission, the Netherlands, UK, and Canada. However, these values were lower than the established Korean soil standard, because the current soil standard was based on human risk. Therefore, the impact on an ecosystem when establishing environmental standard should be considered.
\end{abstract}

Keywords: Cadmium, Ecological protective concentration, Probabilistic ecological risk assessment, Soil

\section{Introduction}

Ecological risk assessment can be classified as probabilistic ecological risk assessment (PERA) and deterministic ecological risk assessment (DERA) according to quality and quantity of toxicity data [1]. PERA is based on species sensitivity distribution (SSD) and DERA uses the lowest toxicity value and assessment factor. Ecological risk assessment is used for effective and efficient environmental management. The environmental standard, guideline, or criteria was established based on risk assessment in developed countries including the Netherlands [2, 3], Australia [4], UK [5], United States [6], and Canada [7]. These countries have an autonomously administered risk assessment methodology for protection of native receptors. In the case of the Netherlands and Canada, the results from risk assessment, which is the lowest value both of human and ecological protective concentration (EPC), are used as an advisory value to set environmental standard, guidelines, or criteria. Presently, soil quality standard in Korea was based on human risk assessment. However, to protect environment there is a need to consider ecological risk assessment like the Netherlands and Canada. For Korean water environment management, EPC was derived by PERA [8, 9], and in the case of soil environment, the study of EPC based on risk assessment was not attempted. Meanwhile, An et al. [1] suggested ecological risk assessment methodology for soils in Korea by comparing methods of developed countries, such as the Nether- lands [2], Canada [7], and European Commission (EC) [10].

For a case study to derive Korean soil EPC, cadmium (Cd) was selected because $\mathrm{Cd}$ was sorted to be given a priority as a toxic chemical [11] and soil contaminant [12]. It exists in nature as a nonessential heavy metal, but is hazardous. Cd is an identified carcinogen for humans by the International Agency for Research on Cancer (group 1) and the United States Environmental Protection Agency (B1: probable human carcinogen), and it is harmful to the ecosystem. In this study, we applied ecological risk assessment for Cd according to An et al. [1] and suggested the maximal permissible levels for soil EPC in Korea.

\section{Materials and Methods}

\subsection{Toxicity Data Collection}

Soil ecotoxicity data was collected from ECOTOX database [13], European Union risk assessment report [10], ecological soil screening level report [14], and other reports regarding Cd [1517].

\subsection{Selection of Data Based on Reliability}

Collected toxicity data was assessed to be of grade 4 on the reliability criteria. Reliability 1 and 2 were used to derive soil EPC,

Received January 28, 2013 Accepted August 30, 2013

${ }^{\dagger}$ Corresponding Author

E-mail: anyjoo@konkuk.ac.kr

Tel: +82-2-2049-6090 Fax: +82-2-2201-6295 duction in any medium, provided the original work is properly cited.

This is an Open Access article distributed under the term of the Creative Commons Attribution Non-Commercial License (http://creativecommons.org/licenses/by-nc/3.0/) 
whereas R3 and R4 were not used. R1 was based on Good Laboratory Practices and provided sufficient background information-test chemical, test process, test unit, moisture contents, and soil properties (e.g., texture, $\mathrm{pH}$, and organic matter); $\mathrm{R} 2$ was based on Science Citation Index Expended papers, which provided sufficient background information; R3 did not provide sufficient background information; and R4 had only the toxicity values.

\subsection{Classification of Acute and Chronic Data}

According to An et al. [1], toxicity data was classified acute or chronic depending on the test duration. In the case of plants and earthworms, acute or chronic toxicity are separated by lesser than or greater than 8 weeks, respectively. In the case of Enchytraeid sp., six weeks was standard for assessing acute and chronic toxicity because it has a shorter duration for reproduction (4-6 weeks) than earthworm (8 weeks) [18]. Twenty-eight days are required for Folsomia candida reproduction and so a period less than 28 days is considered acute for the test duration. In case of Caenorhabditis elegans, less than $72 \mathrm{hr}$ was considered acute. The endpoints of acute and chronic testing were expressed as effective/lethal concentration 50 (EC50/LC50) and no/lowest observed effect concentration (NOEC/LOEC), respectively.

\subsection{Normalization to Standard Soil}

Toxicity test was performed in various soils. In case of natural soil, their property was different based on the location. Organisation for Economic Co-operation and Development (OECD) artificial soil was composed of $70 \%$ sand, $10 \%$ peat moss, and $20 \%$ kaolin. The soil properties such as organic matter and clay contents were related to toxicity results. In EC, UK, the Netherlands, and Australia, the toxicity data was normalized in consideration to the soil properties.

\subsection{Deriving Soil EPC}

Soil EPC was calculated using a domestic soil ecological risk assessment methodology [1]. The methodology is distinct as PERA and DERA depend on quantity and quality of toxicity data. PERA (e.g., statistical extrapolation method [SEM] and SEM acute to chronic ratio $\left.\left[\mathrm{SEM}_{\mathrm{ACR}}\right]\right)$ is based on SSD. SEM is applied to sufficient data for chronic N(L)OEC or acute E(L)C50 for more than 4 taxonomic groups including plants (Magnoliopsida or Liliopsida), earthworm (Clitellata), and macroorganism (Insecta or Secernentea). SEM is calculated from 5 percentile and 50 percentile hazard concentrations (HC5 and HC50) of SSD by $\mathrm{E}_{\mathrm{T}} \mathrm{X}$ program, which was developed by the Rijksinstituut voor Volksgezondheid

Table 1. Acute toxicity data for cadmium

\begin{tabular}{|c|c|c|c|c|c|}
\hline Scientific name & $\begin{array}{c}\text { Exposure } \\
\text { duration (day) }\end{array}$ & Endpoint & $\begin{array}{c}\text { Toxicity value } \\
\text { (mg/kg) }\end{array}$ & $\begin{array}{l}\text { SMAV } \\
(\mathrm{mg} / \mathrm{kg})\end{array}$ & Reference \\
\hline \multicolumn{6}{|l|}{ Class Magnoliopsida } \\
\hline \multirow[t]{2}{*}{ Zea mays (sweet corn) } & 5 & EC50 (shoot growth) & 268 & \multirow{2}{*}{236} & {$[23]$} \\
\hline & 5 & EC50 (root growth) & 208 & & {$[23]$} \\
\hline \multirow[t]{2}{*}{ Sorghum bicolor (sorghum) } & 5 & EC50 (shoot growth) & 61 & \multirow{2}{*}{49} & {$[23]$} \\
\hline & 5 & EC50 (root growth) & 39 & & [23] \\
\hline \multirow[t]{2}{*}{ Triticum aestivum (wheat) } & 5 & EC50 (shoot growth) & 113 & \multirow{2}{*}{105} & {$[23]$} \\
\hline & 5 & EC50 (root growth) & 98 & & {$[23]$} \\
\hline \multicolumn{6}{|l|}{ Class Liliopsida } \\
\hline \multirow[t]{2}{*}{ Cucumis sativus (cucumber) } & 5 & EC50 (shoot growth) & 88 & \multirow{2}{*}{95} & {$[23]$} \\
\hline & 5 & EC50 (root growth) & 102 & & {$[23]$} \\
\hline \multicolumn{6}{|l|}{ Class Clitellata } \\
\hline \multirow[t]{7}{*}{ Eisenia fetida (red worm) } & 2 & LC50 & 374 & \multirow{7}{*}{284} & {$[24]$} \\
\hline & 21 & EC50 (cocoon production) & 108 & & {$[25]$} \\
\hline & 21 & LC50 & 1,260 & & {$[25]$} \\
\hline & 21 & EC50 (cocoon production) & 55.4 & & {$[25]$} \\
\hline & 21 & LC50 & 1,520 & & {$[25]$} \\
\hline & 21 & EC50 (cocoon production) & 73.1 & & {$[25]$} \\
\hline & 21 & LC50 & 477 & & {$[25]$} \\
\hline Eisenia Andrei (tiger worm) & 28 & LC50 & 588 & \multirow[t]{3}{*}{588} & {$[25]$} \\
\hline \multirow[t]{5}{*}{ Enchytraeus albidus (white worm) } & 28 & EC50 (juvenile production) & 158 & & {$[25]$} \\
\hline & 28 & LC50 & 476 & & {$[25]$} \\
\hline & 28 & EC50 (juvenile production) & 72.4 & \multirow[t]{3}{*}{215} & {$[25]$} \\
\hline & 28 & LC50 & 412 & & {$[25]$} \\
\hline & 28 & LC50 & 204 & & {$[25]$} \\
\hline Lumbricus terrestris (earthworm) & 5 & LC50 & 256 & 256 & {$[24]$} \\
\hline \multicolumn{6}{|l|}{ Class Insecta } \\
\hline \multirow[t]{3}{*}{ Folsomia candida (springtail) } & 14 & LC50 & 1,313 & \multirow{3}{*}{1,178} & {$[25]$} \\
\hline & 14 & LC50 & 818 & & {$[25]$} \\
\hline & 14 & LC50 & 1,521 & & {$[25]$} \\
\hline \multicolumn{6}{|l|}{ Class Secernentea } \\
\hline \multirow[t]{5}{*}{ Caenorhabditis elegans (nematode) } & 1 & LC50 & 1,641 & \multirow{5}{*}{718} & {$[26]$} \\
\hline & 1 & LC50 & 741.8 & & {$[27]$} \\
\hline & 1 & LC50 & 505.8 & & {$[27]$} \\
\hline & 1 & LC50 & 921.7 & & {$[27]$} \\
\hline & 1 & LC50 & 337.2 & & {$[27]$} \\
\hline
\end{tabular}

SMAV: species mean acute value, EC: effective concentration, LC: lethal concentration. 
en Milieu (RIVM; National Institute of Public Health and Environment). The HC5 and HC50 were calculated as following equation [19];

$$
\log H C_{\mathrm{p}}=\bar{\chi}-k \cdot s
$$

where, $\mathrm{HC} p$ is hazardous concentration for $\mathrm{p} \%$ of species; $\bar{\chi}$ is mean of log transformed NOEC value; $k$ is extrapolation factor [19]; $s$ is standard deviation of log transformed toxicity data. HC5 and HC50 are automatically calculated as above equation with $90 \%$ confidence interval by the $\mathrm{E}_{\mathrm{T}} \mathrm{X}$ program.

For consideration to land use, HC5 and HC50 apply to residential/agricultural and industrial/commercial land, respectively. $\mathrm{SEM}_{\mathrm{ACR}}$ is applied when chronic data was insufficient but acute data was sufficient. At this time, acute HC5 and HC50 divide the ACR, which is ratio of geometric mean of acute and chronic values of the same species. If it is impossible to calculate ACR or is less than 10, then the ACR is considered with 10 as default value. To consider uncertainty of derived HC5 (or HC50), assessment factor for SSD was applied. In Korea, we do not have standard soil properties yet. In this study, toxicity data was not normalized to Korean standard soil. Therefore, HC5 (or HC50) was divided by 5 . DERA, which is based on an assessment factor method, is obtained from the lowest toxicity values (for residential/agricultural land) or geometric mean of toxicity (for industrial/commercial land) values divided by assessment factor as land use. Finally, the soil EPC is sum of HC5 (or HC50) and background concentration for $\mathrm{Cd}$.

\section{Results and Discussion}

All the soil toxicity data collected for Cd was confirmed by previous references and the reliability of the data was assessed. Soil toxicity data, which belonged to R1 and R2, was listed in Table 1 and 2 In the case of acute toxicity, 5 classes of toxicity data (2 Magnoliopsida, 6 Liliopsida, 17 Clitellata, 3 Insecta, and 5 Secernentea) were sorted (Table 1). Plant acute toxicity data was included for Zea mays, Sorghum bicolor, Triticum aestivum, and Cucumis sativus. Earthworm acute toxicity data was determined using Eisenia fetida and Enchytraeus albidus and acute toxicity

Table 2. Chronic toxicity data for cadmium

\begin{tabular}{|c|c|c|c|c|c|}
\hline Scientific name & $\begin{array}{c}\text { Exposure } \\
\text { duration (day) }\end{array}$ & Endpoint & $\begin{array}{c}\text { Toxicity value } \\
(\mathrm{mg} / \mathrm{kg})\end{array}$ & $\begin{array}{l}\text { SMCV } \\
(\mathrm{mg} / \mathrm{kg})\end{array}$ & Reference \\
\hline \multicolumn{6}{|l|}{ Class Liliopsida } \\
\hline Andropogon scoparius (bluestem) & 84 & LOEC (weight) & 10 & 10 & [16] \\
\hline \multicolumn{6}{|l|}{ Class Clitellata } \\
\hline Eisenia fetida (red worm) & 56 & NOEC (cocoon reproduction) & 39.2 & 39 & [28] \\
\hline \multirow[t]{3}{*}{ Eisenia andrei (tiger worm) } & 84 & NOEC (growth) & 18 & & [17] \\
\hline & 56 & NOEC (juvenile production) & 10 & 15 & [25] \\
\hline & 56 & LOEC (juvenile production) & 18 & & [25] \\
\hline Lumbricus rubellus (earthworm) & 84 & NOEC (survival) & 150 & 150 & {$[17]$} \\
\hline \multicolumn{6}{|l|}{ Class Insecta } \\
\hline \multirow[t]{25}{*}{ Folsomia candida (springtail) } & 28 & NOEC (juvenile production) & 210 & & [25] \\
\hline & 28 & NOEC (juvenile production) & 120 & & [25] \\
\hline & 28 & NOEC (juvenile production) & 67 & & [25] \\
\hline & $28(\mathrm{pH} 6.0)$ & NOEC (reproduction) & 300 & & [29] \\
\hline & $28(\mathrm{pH} 4.5)$ & NOEC (reproduction) & 300 & & [29] \\
\hline & $28(\mathrm{pH} 4.5)$ & NOEC (survival) & 300 & & [29] \\
\hline & $28(\mathrm{pH} 5.0)$ & NOEC (reproduction) & 20 & & {$[29]$} \\
\hline & $28\left(25^{\circ} \mathrm{C}\right)$ & NOEC (survival) & 300 & & {$[30]$} \\
\hline & $28\left(20^{\circ} \mathrm{C}\right)$ & NOEC (reproduction) & 300 & & [30] \\
\hline & $42\left(15^{\circ} \mathrm{C}\right)$ & NOEC (survival) & 300 & & [30] \\
\hline & $42\left(15^{\circ} \mathrm{C}\right)$ & NOEC (reproduction) & 5 & & [30] \\
\hline & 35 & LOEC (reproduction) & 76.5 & & [31] \\
\hline & $33-34$ & LOEC (reproduction) & 153 & 117 & [32] \\
\hline & 28 & NOEC (juvenile production) & 32 & & [25] \\
\hline & 28 & LOEC (juvenile production) & 56 & & [25] \\
\hline & 28 & NOEC (juvenile production) & 180 & & {$[25]$} \\
\hline & 28 & LOEC (juvenile production) & 320 & & [25] \\
\hline & 28 & NOEC (juvenile production) & 18 & & {$[25]$} \\
\hline & 28 & LOEC (juvenile production) & 32 & & [25] \\
\hline & 30 & NOEC (juvenile production) & 71.3 & & [25] \\
\hline & 35 & NOEC (juvenile production) & 148 & & [25] \\
\hline & 42 & NOEC (juvenile production) & 326 & & [25] \\
\hline & 30 & LOEC (juvenile production) & 148 & & [25] \\
\hline & 35 & LOEC (juvenile production) & 326 & & [25] \\
\hline & 42 & LOEC (juvenile production) & 707 & & [25] \\
\hline \multirow[t]{2}{*}{ Proisotoma minuta (springtail) } & 42 & NOEC (survival) & 50 & \multirow{2}{*}{100} & {$[33]$} \\
\hline & 42 & LOEC (survival) & 200 & & [33] \\
\hline \multicolumn{6}{|l|}{ Class Secernentea } \\
\hline \multirow[t]{2}{*}{ Plectus communis (nematode) } & 21 & NOEC (reproduction) & 32 & \multirow{2}{*}{57} & [34] \\
\hline & 21 & LOEC (reproduction) & 100 & & {$[34]$} \\
\hline
\end{tabular}

SMCV: species mean chronic value, LOEC: lowest observed effective concentration, NOEC: no observed effective concentration. 

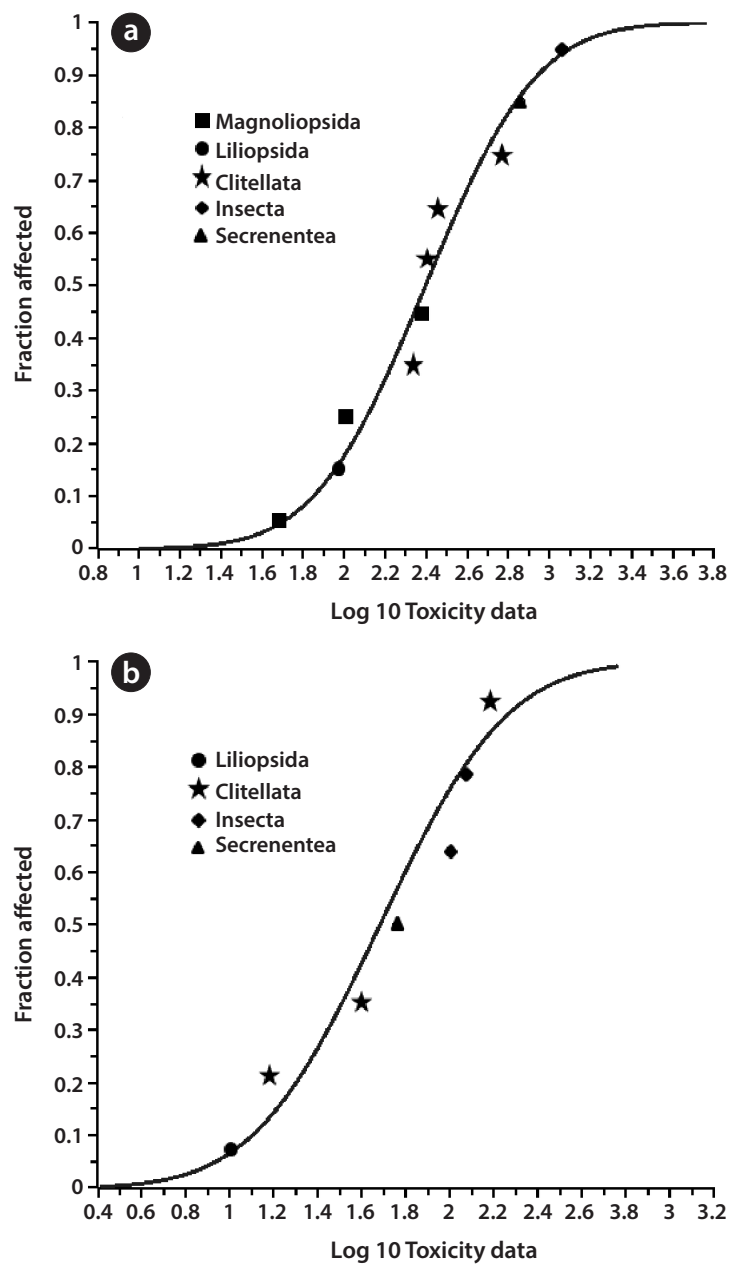

Fig. 1. Species sensitivity distribution data of (a) acute and (b) chronic toxicity to cadmium.

data of Folsomia candida and Caenorhabditis elegans were collected. In the case of chronic toxicity, 4 classes of toxicity data (1 Liliopsida, 7 Clitellata, 28 Insecta, and 2 Secernentea) were sorted (Table 2). Chronic data from one species of plant ( $A n$ dropogon scoparius), chronic data from three species of earthworm (Eisenia fetida, Eisenia andrei, and Lumbricus rubellus) were used in the derivation of EPC. In addition, Folsomia cadida, Proisotoma minuta (Insecta), and Plectus communis (Secernentea) were collected.

Both the acute and chronic data were collected for more than 4 samples, and therefore, soil EPC can be applied using PERA. The input data for SSD that was used was the species mean acute value or species mean chronic value, which was calculated based on the geometric mean of the same species (Fig. 1). The acute HC5 and HC50 were calculated as 46.93 (14.35-91.73) and 248.47 (140.83-438.38) mg/kg, respectively. The chronic HC5 and HC50 were $7.89(1.39-18.39)$ and $47.98(22.32-103.15) \mathrm{mg} / \mathrm{kg}$. Rationally, the toxicity data was to be normalized to Korean standard soil; however, studies of Korean standard soil properties were not done yet. Therefore, assessment factor of 5 was applied. The background concentration of Cd was $0.25 \mathrm{mg} / \mathrm{kg}$ [20]. The final acute and chronic EPC for residential/agricultural land use was
9.39 and $1.58 \mathrm{mg} / \mathrm{kg}$, respectively. The final acute and chronic EPC for industrial/commercial land use was 49.69 and $9.60 \mathrm{mg} /$ $\mathrm{kg}$, respectively.

The soil EPC, which is called as predicted-no-effect-concentration (PNEC) by the EC, soil screening value (SSV) in UK, maximum permissible concentration (MPC) in the Netherlands, soil quality guidelines (SQG) in Canada, and ecological soil screening level (Eco-SSL) in Unite States, of Cd is already reported in EC, UK, the Netherland, Canada, and United States. In European countries, such as UK and the Netherlands, EPC was based on HC5. In EC, they applied SEM method based on the data quality groups from R1 (according to standard test) to R3 (no standard procedure and missing some background information, such as $\mathrm{pH}$, measured concentration of chemicals, statistical results, origin of test species, the range of test concentrations). HC5 of Cd was derived from 21 NOEC data of microflora (R1-R3) by $\mathrm{E}_{\mathrm{T}} \mathrm{X}$ program and it was calculated to be $2.3 \mathrm{mg} / \mathrm{kg}$. Finally, PNEC of Cd was reported as $1.15-2.3 \mathrm{mg} / \mathrm{kg}$, after application of assessment factor of 1-2 because of uncertainty of data [10]. In the Netherlands, maximum permissible addition, which was based on HC5 and was not on the added background concentration, was derived to be $0.79 \mathrm{mg} / \mathrm{kg}$ [21]. This value was based on 13 NOECs for 6 taxonomic groups including 3 macrophyta, 1 mollusca, 5 annelida, 1 isopoda, 2 insecta, and 1 arachnida. Serious risk addition, which was based on HC50, was derived as $12 \mathrm{mg} /$ $\mathrm{kg}$ [21]. The SSV of UK was $1.5 \mathrm{mg} / \mathrm{kg}$ that equates to the EC standards [5]. In the case of Canada, SQG for agricultural, residential/ parkland, commercial, and industrial land were 3.8, 10, 22, and $22 \mathrm{mg} / \mathrm{kg}$ [22]. The Eco-SSL of United States was derived according to receptors involved. The Eco-SSL for plant and soil invertebrates was 32 and $140 \mathrm{mg} / \mathrm{kg}$, respectively [14]. Eco-SSL for plant was calculated from 14 plant species of maximum acceptable toxicant concentration (MATC) values. Eco-SSL for invertebrate was derived from the MATC and EC10 of 3 invertebrate species, such as Eisenia andrei, Folsomia candida, and Plectus acuminatus. Since, Eco-SSL was calculated depending upon the geometric mean of toxicity values for plant or soil invertebrates, these values were higher than other countries. Generally, for the establishment of EPC chronic values of any pollutant are used. Data set and methodology for soil EPC are different with other country. However, soil EPC in Korea was similar with EPC of EC, the Netherlands, UK, and Canada. This reason may be that these countries calculate EPC based on SSD. Meanwhile, the Korean soil standard for residential/agricultural and industrial/commercial land were 4 ( 1 region), 10 ( 2 region), and 60 (3 region) $\mathrm{mg} / \mathrm{kg}$. These values are higher than EPC because the soil standard was based on human risk.

\section{Conclusions}

In present study, we derived soil EPC of Cd in Korea using PERA based on SSD. The soil EPC was calculated according to land use for residential/agricultural and industrial/commercial purposes. As the results, the chronic soil EPCs, which were generally used for EPC in other counties, for residential/agricultural and industrial/commercial lands were derived to be 1.58 and $9.60 \mathrm{mg} / \mathrm{kg}$, respectively. Though these values were similar to EPCs of EC, the Netherlands, UK, and Canada, soil EPCs of Cd were lower than the Koreas soil standard, which was currently established based on human risk. Therefore, there is a need to consider the ecological effects of soil pollutants in the near future. 


\section{Acknowledgments}

This subject is supported by Korea Ministry of Environment as the GAIA Project (2012000540011).

\section{References}

1. An YJ, Lee WM, Nam SH, Jeong SW. Proposed approach of Korean ecological risk assessment for the derivation of soil quality criteria. J. Soil Groundw. Environ. 2010;15:7-14.

2. Traas TP. Guidance document on deriving environmental risk limits. Bilthoven; National Institute of Public Health and Environment [Rijksinstituut voor Volksgezondheid en Milieu]; 2001. Available from:

3. van Vlaardingen PL, Verbruggen EM. Guidance for the derivation of environmental risk limits within the framework of 'international and national environmental quality standards for substances in the Netherlands' (INS). Bilthoven; National Institute of Public Health and Environment [Rijksinstituut voor Volksgezondheid en Milieu]; 2007.

4. National Environment Protection Council. Schedule B5b: guideline on methodology to derive ecological investigation levels in contaminated soils. Canberra: National Environment Protection Council; 2011.

5. Great Britain Environment Agency. Guidance on the use of soil screening values in ecological risk assessment. Bristol: Environment Agency; 2008.

6. US Environmental Protection Agency. Guidance for developing ecological soil screening levels. Washington: US Environmental Protection Agency; 2005.

7. Canadian Council of Ministers of the Environment. A protocol for the derivation of environmental and human health soil quality guidelines. Winnipeg: Canadian Council of Ministers of the Environment; 2006.

8. Korea Ministry of Environment; National Institute of Environmental Research. Development of integrated methodology for evaluation of water environment (III). Incheon: National Institute of Environmental Research; 2006.

9. Nam SH, Lee WM, An YJ. Derivation of ecological protective concentration using the probabilistic ecological risk assessment applicable for Korean water environment: (I) Cadmium. Toxicol. Res. 2012;28:129-137.

10. European Commission. European Union risk assessment report. Cadmium oxide and cadmium metal: Part I. Environment. Luxembourg: Office for Official Publications of the European Communities; 2007.

11. Korea Ministry of Environment. Selection and evaluation of risk concern materials. Gwacheon: Ministry of Environment; 2004.

12. Jeong SW, An YJ. Construction of a chemical ranking system of soil pollution substances for screening of priority soil contaminants in Korea. Environ. Monit Assess. 2012;184:21932204.

13. US Environmental Protection Agency. ECOTOX database [Internet]. Washington: US Environmental Protection Agency; c2013 [cited 2013 Oct 1]. Available from: http://cfpub. epa.gov/ecotox/.

14. US Environmental Protection Agency. Ecological soil screening levels for cadmium. Washington: US Environmental Protection Agency; 2005.

15. Efroymson RA, Will ME, Suter GW II. Toxicological bench- marks for contaminants of potential concern for effects on soil and litter invertebrates and heterotrophic process: 1997 revision. Washington: US Department of Energy; 1997.

16. Efroymson RA, Will ME, Suter GW II, Wooten AC. Toxicological benchmarks for screening contaminants of potential concern for effects on terrestrial plants: 1997 revision. Washington: US Department of Energy; 1997.

17. CANTOX environmental Inc. Ecotoxicology profiles; 2001.

18. Organisation for Economic Co-operation and Development (OECD). Test no. 220: Enchytraeid reproduction test. Paris: OECD Publishing; 2004.

19. Aldenberg T, Jaworsk JS. Uncertainty of the hazardous concentration and fraction affected for nominal species sensitivity distributions. Ecotoxicol. Environ. Saf. 2000;46:1-18.

20. National Institute of Environmental Research. Assessment and establishment of soil pollution standards (II). Incheon: National Institute of Environmental Research; 2005.

21. Lijzen JP, Baars AJ, Otte PF, et al. Technical evaluation of the intervention value for soil/sediment and groundwater: human and ecotoxicological risk assessment and derivation of risk limits for soil, aquatic sediment and groundwater. Bilthoven; National Institute of Public Health and Environment [Rijksinstituut voor Volksgezondheid en Milieu]; 2001.

22. Canadian Council of Ministers of the Environment. Cadmium: Canadian soil quality guidelines for the protection of environmental and human health. Winnipeg: Canadian Council of Ministers of the Environment; 1999.

23. An YJ. Soil ecotoxicity assessment using cadmium sensitive plants. Environ. Pollut. 2004;127:21-26.

24. Fitzpatrick LC, Muratti-Ortiz JF, Venables BJ, Goven AJ. Comparative toxicity in earthworms Eisenia fetida and Lumbricus terrestris exposed to cadmium nitrate using artificial soil and filter paper protocols. Bull. Environ. Contam. Toxicol. 1996;57:63-68.

25. Lock K, Janssen CR. Cadmium toxicity for terrestrial invertebrates: taking soil parameters affecting bioavailability into account. Ecotoxicology 2001;10:315-322.

26. Peredney CL, Williams PL. Utility of Caenorhabditis elegans for assessing heavy metal contamination in artificial soil. Arch. Environ. Contam. Toxicol. 2000;39:113-118.

27. Donkin SG, Dusenbery DB. Using the Caenorhabditis elegans soil toxicity test to identify factors affecting toxicity of four metal ions in intact soil. Water Air Soil Pollut. 1994;78:359-373.

28. Spurgeon DJ, Hopkin SP, Jones DT. Effects of cadmium, copper, lead and zinc on growth, reproduction and survival of the earthworm Eisenia fetida (Savigny): assessing the environmental impact of point-source metal contamination in terrestrial ecosystems. Environ. Pollut. 1994;84:123-130.

29. Sandifer RD, Hopkin SP. Effects of pH on the toxicity of cadmium, copper, lead and zinc to Folsomia candida Willem, 1902 (Collembola) in a standard laboratory test system. Chemosphere 1996;33:2475-2486.

30. Sandifer RD, Hopkin SP. Effects of temperature on the relative toxicities of $\mathrm{Cd}, \mathrm{Cu}, \mathrm{Pb}$, and $\mathrm{Zn}$ to Folsomia candida (Collembola). Ecotoxicol. Environ. Saf. 1997;37:125-130.

31. Crouau Y, Moia C. The relative sensitivity of growth and reproduction in the springtail, Folsomia candida, exposed to xenobiotics in the laboratory: an indicator of soil toxicity. Ecotoxicol. Environ. Saf. 2006;64:115-121.

32. Crouau Y, Chenon P, Gisclard C. The use of Folsomia candida (Collembola, Isotomidae) for the bioassay of xenobiotic sub- 
stances and soil pollutants. Appl. Soil Ecol. 1999;12:103-111. 33. Nursita AI, Singh B, Lees E. The effects of cadmium, copper, lead, and zinc on the growth and reproduction of Proisotoma minuta Tullberg (Collembola). Ecotoxicol. Environ. Saf. 2005;60:306-314.
34. Kammenga JE, Van Koert PH, Riksen JA, Korthals GW, Bakker J. A toxicity test in artificial soil based on the life-history strategy of the nematode Plectus acuminatus. Environ. Toxicol. Chem. 1996;15:722-727. 